\title{
Purification and characterization of lipoxygenase from mung bean (Vigna radiata L.) germinating seedlings
}

\author{
Raveendra Aanangi ${ }^{1}$ Kasi Viswanath Kotapati ${ }^{2} \cdot$ Bhagath Kumar Palaka $^{2}$. \\ Thyagaraju Kedam $^{1} \cdot$ Nirmala Devi Kanika ${ }^{1} \cdot$ Dinakara Rao Ampasala $^{2}$
}

Received: 7 November 2015/Accepted: 26 April 2016/Published online: 17 May 2016

(c) The Author(s) 2016. This article is published with open access at Springerlink.com

\begin{abstract}
This study reports purification and characterization of lipoxygenase protein from mung bean germinating seedlings. Lipoxygenases (LOXs) are key enzymes in seed germination. The purified mung bean LOX has resolved into two peaks by chromatofocusing, one has highest LOX activity with an isoelectric point of 5.84 and the other has lowest LOX activity with an isoelectric point of 5.52. The purified LOX has molecular mass of approximately $97 \mathrm{kDa}$ and showed high activity with linoleic acid than linolenic acid and arachidonic acid. The optimal activity of LOX was observed at $\mathrm{pH} 6.5$ and temperature $35^{\circ} \mathrm{C}$. Far-UV circular dichroism (CD) studies revealed that the purified mung bean LOX possess secondary structural elements with significant $\alpha$-helix and $\beta$-strands. Further, the secondary structure of mung bean LOX was stable up to $60{ }^{\circ} \mathrm{C}$ at $\mathrm{pH}$ 6.5. Biophysical and chemical properties of the mung bean LOX are similar to the other legume LOXs and may be considered as type-1 LOX.
\end{abstract}

Keywords Chromatofocusing · Circular dichroism · Mung bean · Plant lipoxygenases $\cdot$ Protein purification

$\begin{array}{ll}\text { Abbreviations } \\ \text { LOX } & \text { Lipoxygenase } \\ \text { PUFAs } & \text { Polyunsaturated fatty acids } \\ \text { ETYA } & \text { Eicosatetraenoic acid } \\ \text { DE-52 } & \text { Diethyl amino ethyl cellulose }\end{array}$

Dinakara Rao Ampasala ampasaladr@bicpu.edu.in

1 Department of Biochemistry, Sri Venkateswara University, Tirupati 517 502, Andhra Pradesh, India

2 Centre for Bioinformatics, School of Life sciences, Pondicherry University, Puducherry 605014, India
NDGA Nordihydroguaiaretic acid

CD Circular dichroism

TBA Thiobarbituric acid

TCA Trichloro acetic acid

MDA Malondialdehyde

X-Gal 5-Bromo-4-chloro-3-indolyl $\beta$-Dgalactopyranoside

PMSF Phenylmethylsulfonyl fluoride

\section{Introduction}

Lipoxygenases (LOXs, linoleate: oxygen oxidoreductases, EC: 1.13.12.11) represent a large gene family of non-heme, non-sulfur iron or manganese containing dioxygenases which are ubiquitously distributed throughout nature indicating the biological and evolutionary importance of these enzymes (Joo and Oh 2012). LOXs catalyze the regio- and stereo-specific dioxygenation of polyunsaturated fatty acids (PUFAs) containing (1Z, 4Z)-pentadiene system (Kuhn and Thiele 1999). Evidences suggested that the primary products generated by these enzymes are called as hydroperoxides, which act as substrates for the synthesis of short chain carbonyl compounds, involved in plant growth, hostpathogen interactions, defense, development and senescence (Brash 1999; Gfeller et al. 2010; Siedow 1991). LOXs are also known to play a major role in production of volatile substances, which influence the flavor and aroma of food from the plants and have wide applications in food industry as they play important role in maintaining food quality and the aroma of food grains (Suzuki et al. 2010).

Germination is the most critical step in the life cycle of spermatophytes and represents the entry of plants into the 
ecosystem, during which a seed from a dormant embryonic state enters into a highly dynamic phase leading to seedling establishment (Weitbrecht et al. 2011). Germination begins with imbibition and terminates with seed coat rupture and radicle protrusion through the endosperm (Kong et al. 2015). During germination, lipid bodies are degraded in seeds by a new set of proteins, among which, LOXs are playing an important role (Feussner et al. 2001).

During the past few decades, many isoforms of LOX were identified from different plants and their physical and enzymatic properties are characterized. Although occurrence of LOXs in vegetables and fruits is known, it has been reported that legumes are rich source for LOXs, among them soybean seed LOXs were well studied at molecular level (Feussner and Wasternack 2002; Kolomiets et al. 2001). Three isoforms of LOX were identified and characterized from soybean seeds based on their $\mathrm{pH}$ optimum, substrate specificity, product formation, kinetic parameters and enzyme stability (Axelrod et al. 1981; Clemente et al. 2000; Kolomiets et al. 2001). Apart from soybean, other legumes have also been reported as good source of LOX proteins. Legumes are inexpensive source of LOX proteins and particularly high level of LOX activities were identified from various legume seeds (Rao et al. 1998). Mung bean was identified as a novel source of LOX in the natural production of green-note aroma compound, hexanal, it is also considered as a cheap and readily available staple food in Asia (Chow et al. 2007). Further, mung bean and its seedlings have been used as a source of hydroperoxide lyase enzyme (Rehbock et al. 1998). Previously, high levels of LOX activity have been reported in germinating seedlings of mung bean (Devi et al. 2005; Rao et al. 1998). Earlier we reported a full-length LOX from mung bean germinating seedlings, during developmental stage more level of LOX expression was observed (Kotapati et al. 2015). However, no reports were available to date on purification and characterization of LOX from mung bean.

In the present study, considering the importance of LOX proteins in food industry, a report on the isolation and biochemical properties of purified LOX from mung bean seedlings is presented.

\section{Materials and methods}

\section{Plant material and chemicals}

The mung bean seeds were obtained from Sri Venkateswara Agricultural University, Tirupati. Soybean LOX, ETYA, Linoleic acid, Linolenic acid, Arachidonic acid, Sephadex G-100, DE-52, Poly Buffer Exchangers 94 (PBE-94), Phenyl methyl sulfonyl fluoride (PMSF), EDTA,
Acrylamide, Bis-acrylamide, Coomassie brilliant blue, Lauryl sulphate (SDS) and protein size markers were procured from Sigma Chemicals Co (St. Louis, MO, USA). NDGA was a generous gift from department of chemistry, S.V. University. All other chemicals were reagent grade procured from Merck, Mumbai, India.

\section{LOX protein extraction and purification}

Extraction and purification methods for mung bean LOX was adopted from Clemente et al. (2000) and Roopashree et al. (2006) with minor modifications. In brief, finely ground powder of mung bean seedlings was extracted with ice cold hexane to make it defatted. About $30 \mathrm{~g}$ of defatted fine powder was extracted with $300 \mathrm{ml}$ of $50 \mathrm{mM}$ sodium phosphate buffer, $\mathrm{pH} 6.8$, at $4{ }^{\circ} \mathrm{C}$ for $3-4 \mathrm{~h}$ and centrifuged at $10,000 \times g$ for $30 \mathrm{~min}$. The fine supernatant was dialyzed against $25 \mathrm{mM}$ sodium phosphate buffer ( $\mathrm{pH}$ 6.8) for $24 \mathrm{~h}$ with three buffer changes and centrifuged at $25,000 \times g$ for $20 \mathrm{~min}$. The supernatant was dialyzed against $40 \%$ poly ethylene glycol 20,000 for $16 \mathrm{~h}$ and then centrifuged at $25,000 \times g$ for $20 \mathrm{~min}$. The dialyzed sample was applied to Sephadex G-150, gel filtration column $(100 \times 2.5 \mathrm{~cm})$ and fractions were collected with a fraction size of $2.5 \mathrm{ml}$ per tube at a flow rate of $20 \mathrm{ml} / \mathrm{h}$. The active fractions were pooled and further purified by ion exchange chromatography (DEAE 52, column $3 \times 30 \mathrm{~cm})$. Bound protein was eluted using a linear salt gradient $[0 \mathrm{mM}(150 \mathrm{ml})$ to $300 \mathrm{mM}(150 \mathrm{ml})]$ sodium phosphate buffer [pH 6.8] and fractions were assayed for protein and LOX activity. At the end of this purification step, two protein fractions were obtained, one with high and the other without LOX activities. To determine the isoelectric points of mung bean seedling LOX, the peak with high LOX activity fractions was pooled, concentrated and dialyzed to remove salt, centrifuged at $25,000 \times g$ for 20 min at $4{ }^{\circ} \mathrm{C}$ and the supernatant was applied on the PBE-94 chromatofocusing column $(3 \times 12 \mathrm{~cm})$ which was saturated with $5 \mathrm{ml}$ of gradient buffer (Poly buffer 94, 1: $8, \mathrm{pH} 4.0$ ) to create a $\mathrm{pH}$ gradient in column. The flow rate was adjusted to $8 \mathrm{ml} / \mathrm{h}$ and elute was collected in $1 \mathrm{ml}$ per fraction. The protein in each fraction was read at $280 \mathrm{~nm}$ and assayed for LOX activity. The $\mathrm{pH}$ of each fraction was determined by using a KL-009 (1B) pocket size $\mathrm{pH}$ meter. All purification steps were performed at $4{ }^{\circ} \mathrm{C}$ until otherwise mentioned.

\section{SDS-PAGE}

SDS-PAGE was performed according to the method of Laemmli (1970) using $12 \%$ gels. The proteins were stained with Coomassie brilliant blue R-250 in methanol:water:acetic acid (60:30:10) for few hours and 
then washed in destaining buffer until protein bands appear.

\section{Activity staining}

Sample containing 50-100 $\mu \mathrm{g}$ LOX protein of germinated seedlings extract was separated on $8 \%$ polyacrylamide gel electrophoresis without adding SDS to the gel and running buffer (0.025 M Tris- $\mathrm{HCl}$ and $0.192 \mathrm{M}$ glycine, $\mathrm{pH} 8.8)$ at $4{ }^{\circ} \mathrm{C}$ as suggested by Heydeck and Schewe (1984). In brief, following the isozymes separation, gels were washed briefly with phosphate buffer ( $\mathrm{pH}$ 6.8), and incubated in substrate solution for $5 \mathrm{~min}$ at room temperature. After incubation the gels were washed quickly with $100 \mathrm{mM}$ phosphate buffer ( $\mathrm{pH}$ 6.8), and incubated in staining solution with $O$-diansidine- $\mathrm{HCl}$ (50 mg $O$-Diansidine- $\mathrm{HCl}$ dissolved in $10 \mathrm{ml}$ absolute ethanol under heating and add this solution to $90 \mathrm{ml}$ of $100 \mathrm{mM}$ phosphate buffer, $\mathrm{pH}$ 6.8). The electropherogram which has LOX enzymes converts the fatty acid substrate into fatty acid hydroperoxides. These hydroperoxides oxidize both the amino groups of 3-3' methoxybenzidine hydrochloride forming the chromophores. The chromophores give a reddish brown colour by which the presence of isoenzymes could be localized.

\section{Enzyme assay}

Lipoxygenase activity was measured as previously described using Jasco V-530 UV-VIS spectrophotometer at $25^{\circ} \mathrm{C}$ by monitoring the increase in absorbance over a period of time at $234 \mathrm{~nm}$ (Reddanna et al. 1990). The typical reaction mixture contains $2.8 \mathrm{ml}$ of $50 \mathrm{mM}$ sodium phosphate buffer ( $\mathrm{pH}$ 6.5), appropriate volume of enzyme $(10-100 \mu \mathrm{l})$ and the reaction was initiated by addition of substrate to the reaction mixture and maintained to have $250 \mu \mathrm{M}$ for linoleic acid in the total volume. One unit of enzyme activity is defined as the $\mu \mathrm{mol}$ of hydroperoxide formed per $\min ^{-1} \mathrm{mg}^{-1}$ protein.

\section{Kinetic parameters}

\section{Effect of $\mathrm{pH}$ and temperature}

The optimum $\mathrm{pH}$ for mung bean LOX activity was investigated using linoleic acid as substrate at $25{ }^{\circ} \mathrm{C}$ within the $\mathrm{pH}$ range of 3.0-10.0. The effect of ionic strength on mung bean LOX enzyme activity was tested using different concentrations of sodium phosphate buffer $(\mathrm{pH}$ 6.5) from 10 to $200 \mathrm{mM}$. To figure out the optimum temperature of mung bean LOX enzymes, activity was measured using pre-incubated standard assay mixture for $10 \mathrm{~min}$ at the indicated temperature $\left(20-80{ }^{\circ} \mathrm{C}\right)$. After incubation, samples were cooled to $25{ }^{\circ} \mathrm{C}$ and the remaining LOX activity was determined.

The kinetic parameters of mung bean seedling LOX were measured under standard assay conditions using substrate concentrations in the range of $2-400 \mu \mathrm{M}$. All determinations were done in duplicate and respective kinetic parameters were calculated from Line-weaver Burk (LB) plot.

\section{Effect of inhibitors on mung bean seedling LOX activity}

Effect of two known LOX inhibitors on mung bean LOX activity was investigated under standard conditions using different concentrations of ETYA $(0-300 \mu \mathrm{M})$ and NDGA $(0-500 \mu \mathrm{M})$. The stock solutions of both inhibitors were prepared in $100 \%$ alcohol. The inhibitors were pre-incubated with enzyme for $5 \mathrm{~min}$ and assay was performed as mentioned in previous sections.

\section{Circular dichroism (CD) studies of mung bean seedling LOX}

Circular dichroism (CD) experiments were carried out using Jasco J-715 Polari meter. CD measurements were performed using homogeneous samples at a protein concentration of $60-80 \mu \mathrm{g} / \mathrm{ml}$ in $10 \mathrm{mM}$ phosphate buffer at appropriate $\mathrm{pH}$ as described by (Barone et al. 1999). FarUV CD spectra were recorded from 200 to $250 \mathrm{~nm}$ using $0.1 \mathrm{~cm}$ light path quartz cuvettes under continuous nitrogen flow. A special acquisition spacing of $0.1 \mathrm{~nm}$ was used and each spectrum was averaged four times and smooth curves were made. The thermal stability of mung bean LOX was investigated from 25 to $80{ }^{\circ} \mathrm{C}$ at different $\mathrm{pH}$ conditions.

\section{Results and discussion}

\section{Purification and characterization}

The enzyme was purified to 27 folds by chromatographic (gel filtration, ion exchange and chromatofocusing) methods. The detailed description of mung bean LOX purification is given in Table 1 . Loss in LOX activities (40-50 \%) of broad bean, french bean and horse bean was reported when ammonium sulfate fractionation was used as an initial purification step (Feussner and Wasternack 2002). Hence ammonium sulfate precipitation was avoided in the 
Table 1 Summary of purification methods employed for lipoxygenase purification from mung bean germinating seedlings

\begin{tabular}{|c|c|c|c|c|c|}
\hline Method & $\begin{array}{l}\text { Protein } \\
(\mathrm{mg})\end{array}$ & $\begin{array}{l}\text { Total activity } \\
\text { (units) }\end{array}$ & $\begin{array}{l}\text { Specific activity } \\
\text { (U/mg) }\end{array}$ & $\begin{array}{l}\text { Yield } \\
(\%)\end{array}$ & $\begin{array}{l}\text { Purification } \\
\text { (fold) }\end{array}$ \\
\hline Crude extract & 5183 & 30,224 & 5.83 & 100 & 1 \\
\hline Albumin fraction & 1040 & 20,976 & 20.20 & 69.0 & 3.5 \\
\hline Sephadex G-100 & 625 & 11,900 & 19.04 & 39.4 & 3.3 \\
\hline DEAE-DE-52 & 390 & 10,400 & 26.67 & 34.4 & 4.6 \\
\hline \multicolumn{6}{|c|}{ Chromatofocussing (PBE-94) } \\
\hline Peak-1 (pI-5.84) & 1.25 & 200 & 160.0 & 1.0 & 27.4 \\
\hline Peak-2 (pI-5.52) & 0.63 & 7.0 & 11.11 & 0.02 & 2.0 \\
\hline
\end{tabular}

initial step of purification. Instead, an albumin-enriched fraction was obtained as mentioned by Kuo et al. (2006) and is considered as initial step for further purification. Proteins with purification fold 3.5 were obtained in albumin fraction. During gel filtration chromatography a broad
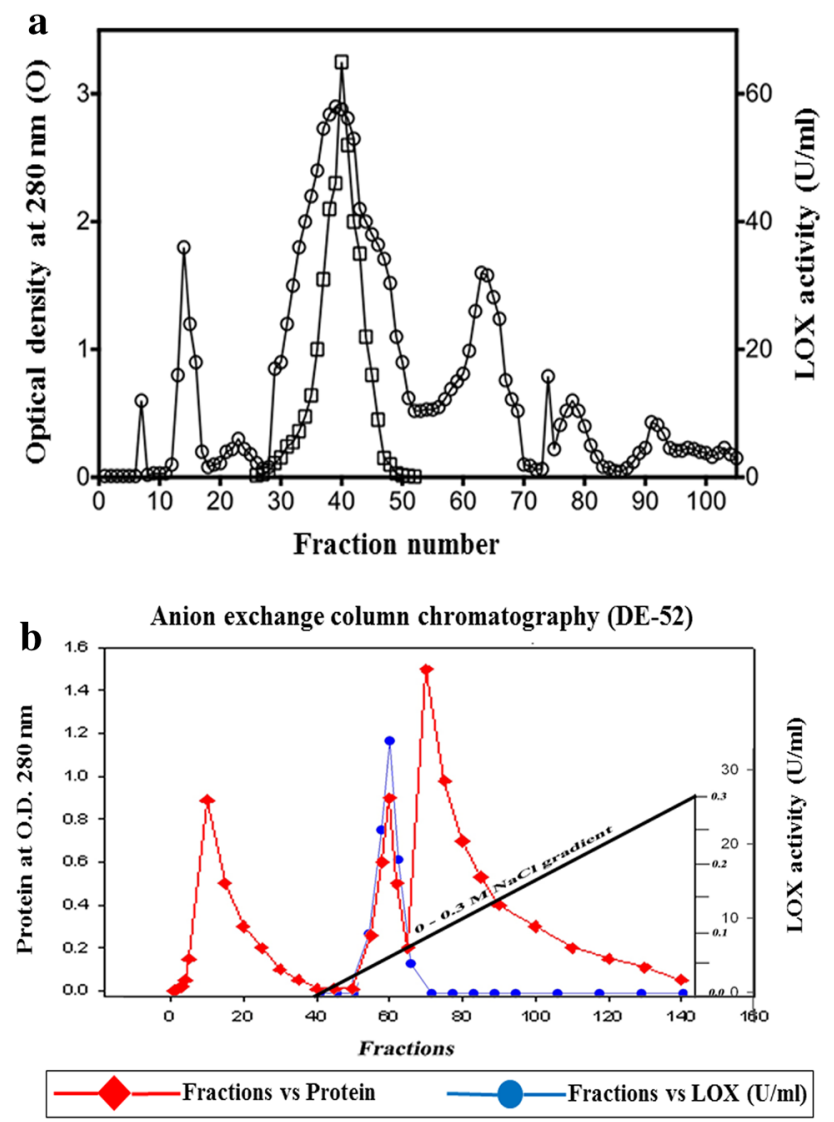

Fig. 1 a Gel filtration chromatography of mung bean LOX on Sephadex G-150 column. Fractions of $5 \mathrm{ml}$ were collected and assayed for protein at $280 \mathrm{~nm}$ and LOX activity at $234 \mathrm{~nm}$. b Anion exchange chromatography of mung bean LOX on DE-52 column, $0.0-0.3 \mathrm{M} \mathrm{NaCl}$ salt gradient was used to elute LOX protein from the column. Fractions of $2.5 \mathrm{ml}$ were collected and assayed for protein at $280 \mathrm{~nm}$ and LOX activity at $234 \mathrm{~nm}$ single peak of mung bean LOX protein was eluted with purification fold of 3.8 and a specific activity of 22.24 $\mathrm{U} / \mathrm{mg}$ protein. Finally, anion exchange chromatography yielded two protein fractions upon $\mathrm{NaCl}$ salt gradient elution, one with high and the other without LOX activity with purification fold of 4.6 with $26.7 \mathrm{U} / \mathrm{mg}$ specific activity (Fig. 1a, b; Table 1) and which was considered for further characterization. The mung bean LOX active protein fraction was resolved into two isozymes on chromatofocusing (Fig. 2). The first isozyme has an isoelectric point of 5.84 and showed high specific activity (160 U/mg) with purification fold of 27 . The second has an isoelectric point

\section{Chromatofocussing (PBE-94) Column chromatography}

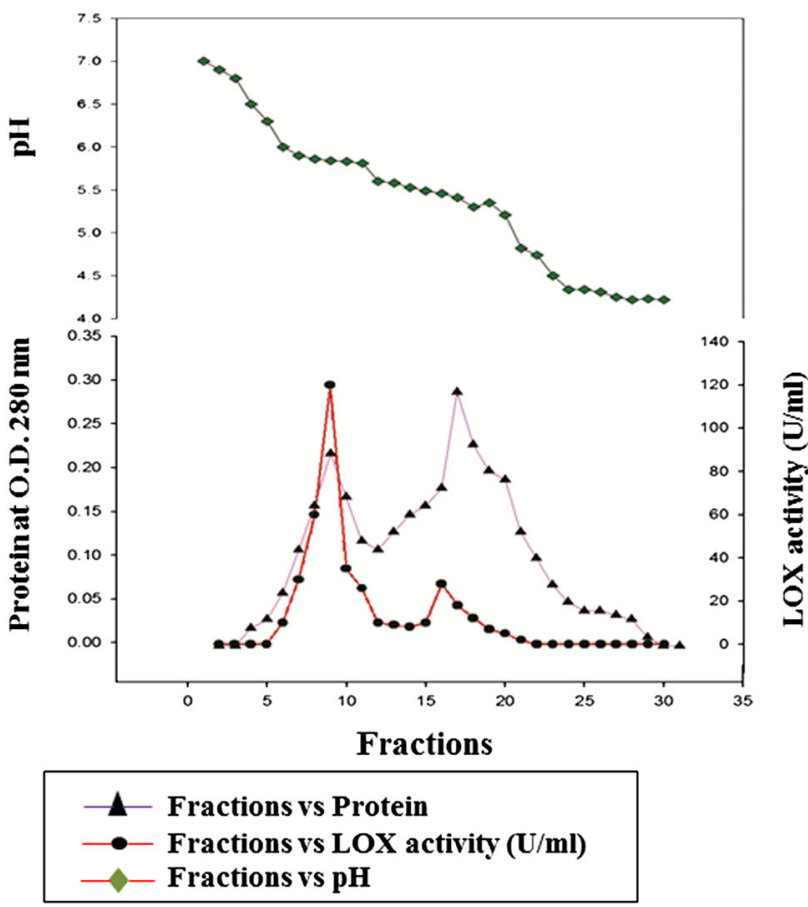

Fig. 2 Isoelectrofocussing column chromatography of mung bean LOX on PBE-94 column. Fractions of $1.0 \mathrm{ml}$ were collected and assayed for protein at $280 \mathrm{~nm}$ and LOX activity at $234 \mathrm{~nm}$ 
of 5.52, showed low specific activity $(11.11 \mathrm{U} / \mathrm{mg})$ and with purification fold of 2.0, which eventually lost its activity during the purification process. The $\mathrm{p} I$ values of mung bean LOX are closely related to English pea and soybean LOX isoenzymes (Eriksson and Svensson 1970). The SDS-PAGE purified mung bean LOX (first isozyme fraction) showed a single band with an approximate molecular mass of $97 \pm 5 \mathrm{kDa}$ and greater than $90 \%$ purity (Fig. 3a). The molecular mass of mung bean LOX is similar to broad bean, faba beans, soybean, durum wheat and pea LOXs as reported (Barone et al. 1999; Clemente et al. 2000). Activity staining on native PAGE of mung $\mathbf{a}$

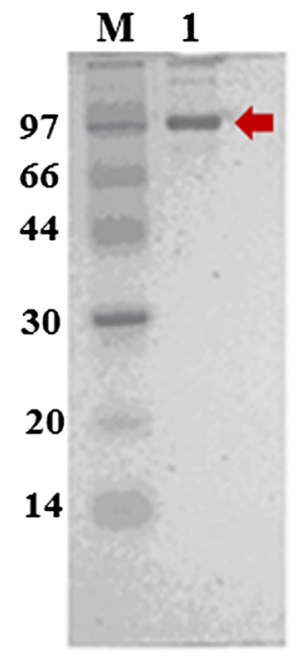

b

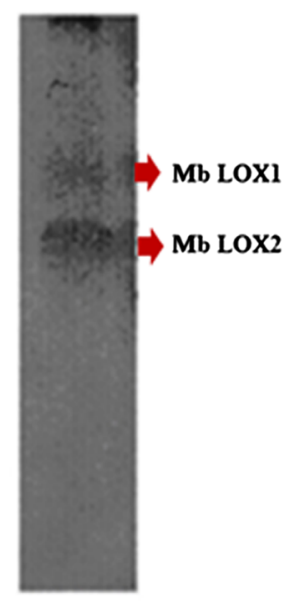

Fig. 3 a SDS-PAGE analysis of LOX purified from mung bean seedlings. Lane $M$ molecular weight standards (in $\mathrm{kDa}$ ). Lane 1 Anion exchange (DE-52) Purified mung bean LOX (peak1). b Native PAGE analysis- Mung bean LOX isoenzymes (Mb LOX1 and Mb LOX2) stained with $O$-Diansidine- $\mathrm{HCl}$ under native conditions run at $4{ }^{\circ} \mathrm{C}$ bean seedlings extract showed two brown enzymatically active bands which indicate the presence of two LOX isoenzymes during seedling growth (Fig. 3b). Based on the activity staining, presence of multiple bands suggest that perhaps two or more isoenzymes will be expressed in later stages of plant development and each will play important roles in plant growth and defense (Haydar and Hadziyev 1973).

\section{Kinetic studies}

The optimal $\mathrm{pH}$ for mung bean LOX was found to be 6.5. More than $50 \%$ loss in mung bean LOX activity was observed below $\mathrm{pH} 4.5$ or above $\mathrm{pH}$ 8.0; however, considerable LOX activity was noted with in a $\mathrm{pH}$ range 4.5-8.0 (Fig. 4a). The effect of ionic strength on mung bean LOX enzymatic activity revealed the maximal activity at $50 \mathrm{mM}$ concentration of sodium chloride (Data not shown). Although appreciable LOX activities were observed between 50 and $150 \mathrm{mM}$ salt concentrations, reduced enzyme activities were noted below $50 \mathrm{mM}$ salt concentration (Fig. 4a). Mung bean LOX showed maximal activity at $35^{\circ} \mathrm{C}$ and retain its activity up to $60{ }^{\circ} \mathrm{C}$ (Fig. 4b). However, significant decrease in enzyme activity was observed at higher temperature (over $50{ }^{\circ} \mathrm{C}$ ). The optimal $\mathrm{pH}$ and temperature studies of mung bean LOX are closely identical to other plant LOXs (Feussner and Wasternack 2002; Kolomiets et al. 2001).

Substrate specificity of mung bean LOX was determined using linoleic, linolenic and arachidonic acids, and kinetic constants were obtained (Table 2). The apparent $K_{\mathrm{m}}$ of mung bean LOX for three substrates tested is 79.79, 135.5 and $253.1 \mu \mathrm{M}$ (Fig. 5). Given data suggest that linoleic acid is preferred substrate for mung bean LOX when compared with linolenic and arachidonic acids. The
Fig. 4 Optimal conditions for mung bean LOX activity. a Effect of $\mathrm{pH}$ on purified mung bean LOX. Different buffers were prepared at $50 \mathrm{mM}$ concentration and adjusted to defined $\mathrm{pH}$ values. b Effect of temperature on purified mung bean LOX. Samples were pretreated for $10 \mathrm{~min}$ at given temperature and then assayed for LOX activity under standard conditions
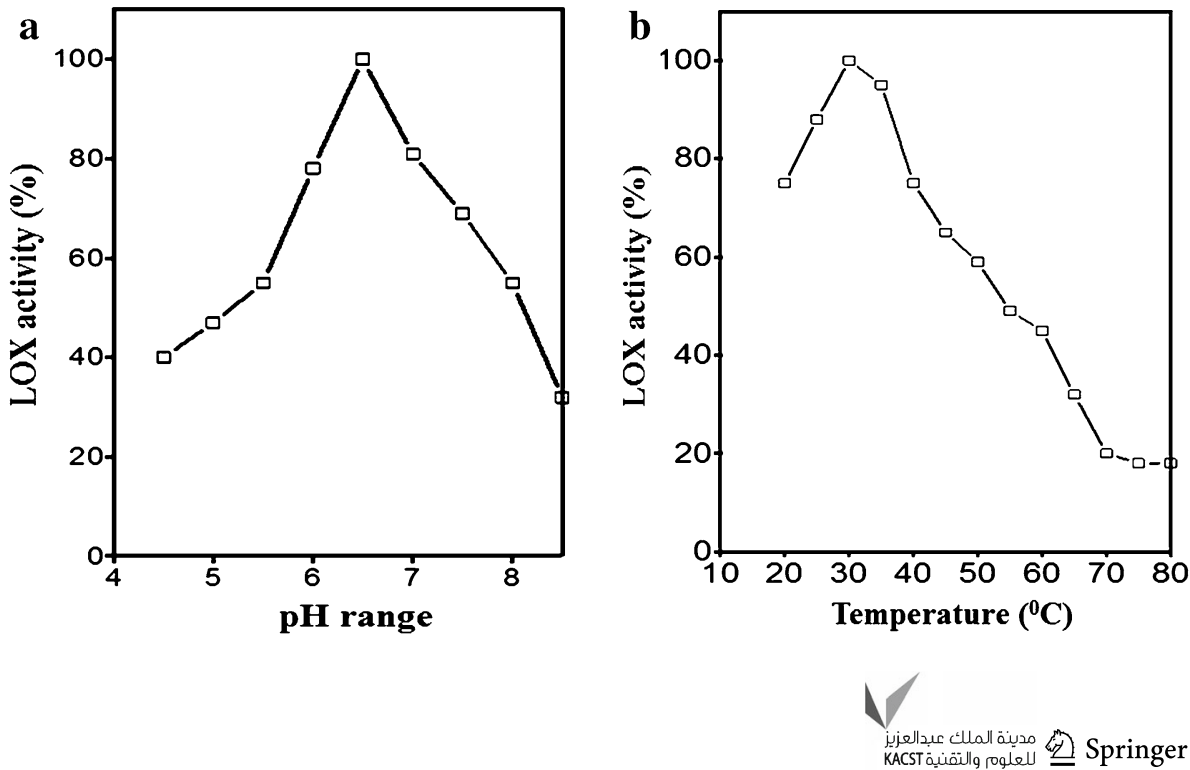
Table 2 Characteristics of lipoxygenase purified from mung bean seedlings

\begin{tabular}{ll}
\hline Parameter & Mung bean LOX \\
\hline $\mathrm{pH}$ optimum & 6.5 \\
Isoelectric points $(\mathrm{pI})$ & 5.84 and 5.52 \\
Temperature $\left({ }^{\circ} \mathrm{C}\right)$ & $35-40$ \\
Ionic strength $(\mathrm{mM})$ & 50 \\
$K_{\mathrm{m}}(\mu \mathrm{M})$ & \\
Linoleic acid & 79.79 \\
Linolenic acid & 135.5 \\
Arachidonic acid & 253.1 \\
$V_{\text {max }}(\mu \mathrm{mol} / \mathrm{min})$ & \\
Linoleic acid & 9.32 \\
Linolenic acid & 7.31 \\
Arachidonic acid & 8.63 \\
IC50 $(\mu \mathrm{M})$ & \\
ETYA & 20 \\
NDGA & 48 \\
Structure & Alpha-helix and beta sheet \\
Products (absorption max) & 234 and 278 \\
Inflection point & $60{ }^{\circ} \mathrm{C}$ (pH 6.8) \\
& $50{ }^{\circ} \mathrm{C}(\mathrm{pH} 9.0$ and 5.0) \\
\hline
\end{tabular}

apparent $K_{\mathrm{m}}$ and $V_{\max }$ values of mung bean LOX are closely relevant with the other legumes like germinating barley (van Aarle et al. 1991), soybean (Axelrod et al. 1981; Dainese et al. 2010), durum wheat semolina (Barone et al. 1999) and broad bean (Clemente et al. 2000) LOX isoenzymes.

Two well-known LOX inhibitors, ETYA and NDGA, were tested to investigate the effect on mung bean LOX (Fig. 6). The calculated $\mathrm{IC}_{50}$ of ETYA and NDGA with mung bean LOX were $18.18 \pm 1.2$ and $48.07 \pm 3.2 \mu \mathrm{M}$, respectively. The inhibition kinetics of two LOX inhibitors, ETYA and NDGA, followed competitive and non-competitive mode of inhibition, respectively. Similar kind of inhibition constants were reported for soybean type-1 LOX and type-2 LOX, and human LOX-5 (Kohyama et al. 1997; Kolomiets et al. 2001; Nagabhushana et al. 2002).

\section{Circular dichroism (CD) studies}

Far UV-circular dichroism spectra of mung bean LOX showed a negative dip at 208 and $222 \mathrm{~nm}$, indicating the existence of predominant secondary structure with significant $\alpha$-helix and $\beta$-strands (Fig. 7a). Further, temperature effect on mung bean LOX as function of its secondary structure at optimal $\mathrm{pH}$ showed that the secondary structures were stable up to $60{ }^{\circ} \mathrm{C}$ and the secondary structures were destabilized upon further increase of temperature (Fig. 7b). Thermal stability of mung bean LOX was also
$V \max =9.32$

$\mathrm{Km}=79.79$

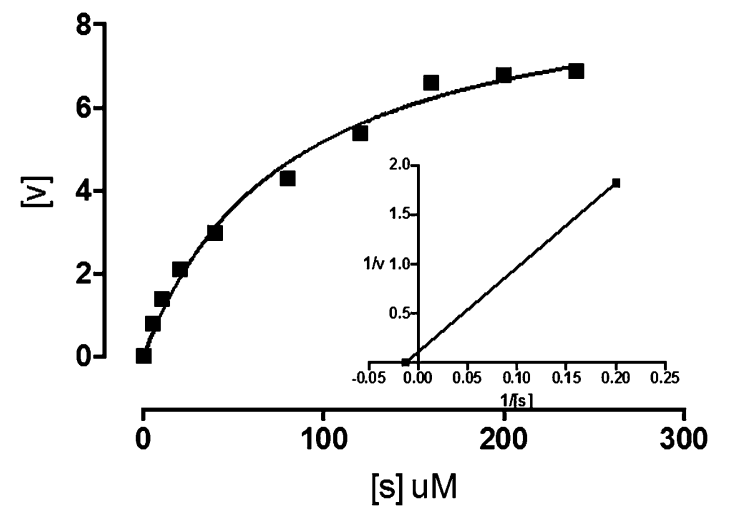

Fig. 5 Effect of substrate concentration on mung bean LOX and determination of Vmax and Km. Data showed for linoleic acid as substrate for mung bean LOX

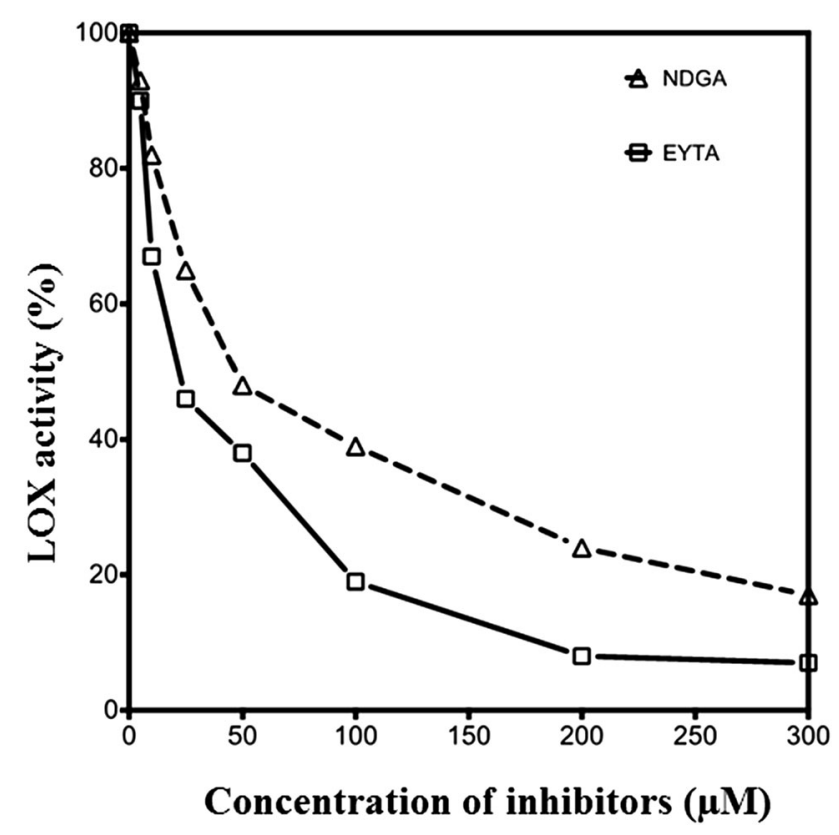

Fig. 6 Effect of inhibitors on mung bean LOX activity. Square ETYA and upright triangle NDGA

depicted by measuring the dichroic activity at $222 \mathrm{~nm}$ as a function of temperature. A Sigmoid decrease in ellipticity at $222 \mathrm{~nm}$ was observed with increase in temperature and the inflection point of $60{ }^{\circ} \mathrm{C}$ at optimal $\mathrm{pH}$. The $\mathrm{CD}$ data of mung bean LOX is consistent with LOX activities measured at different temperatures whereas loss in enzymatic activities was observed over $60^{\circ} \mathrm{C}$ at optimal $\mathrm{pH}$. These data suggest that, the mung bean LOX secondary structure is $\mathrm{pH}$ and temperature dependent and significant loss in enzymatic activity is due to loss in secondary structure of protein (Graff et al. 1990). 


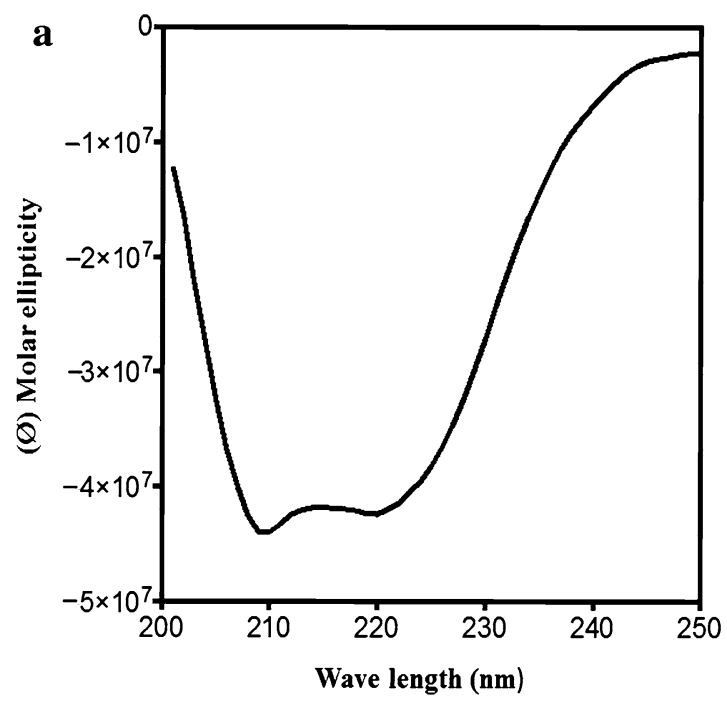

Fig. 7 Circular dichroism analysis of purified mung bean LOX. a Far-UV CD spectra. Measurements were made at $25^{\circ} \mathrm{C}$ in $10 \mathrm{mM}$ phosphate buffer ( $\mathrm{pH}$ 6.5). b Temperature effect on mung bean LOX

\section{Conclusions}

In conclusion, we have purified and characterized the mung bean lipoxygenase by biophysical and biochemical analysis. Mung bean LOX that we purified has similar properties like soybean LOX1 type. Our findings also suggest that presence of multiple isoforms in seedlings perhaps play key roles in developmental stages. Although the predominant isoform in mung bean is LOX1, detailed characterization of other isoforms can also be considered useful as the by-products of LOX subtypes have industrial applications. Our recent cloning data also suggest the presence of multiple isoforms in mung bean. As mung bean is one of the food sources, the present study will serve as basis for detailed analysis of mung bean LOX isoforms and their roles in mung bean related food products.

Acknowledgments Sincere thanks to the Department of Biotechnology (No: BT/PR10858/AGR/02/682/2008), New Delhi for financial support. Special thanks to Chairman, Molecular Biophysics Unit, Indian Institute of Science, Bangalore for providing CD spectrophotometer and some essential chemicals and reagents.

\section{Compliance with ethical standards}

Conflict of interest The authors state no conflict of interest.

Open Access This article is distributed under the terms of the Creative Commons Attribution 4.0 International License (http:// creativecommons.org/licenses/by/4.0/), which permits unrestricted use, distribution, and reproduction in any medium, provided you give appropriate credit to the original author(s) and the source, provide a link to the Creative Commons license, and indicate if changes were made.

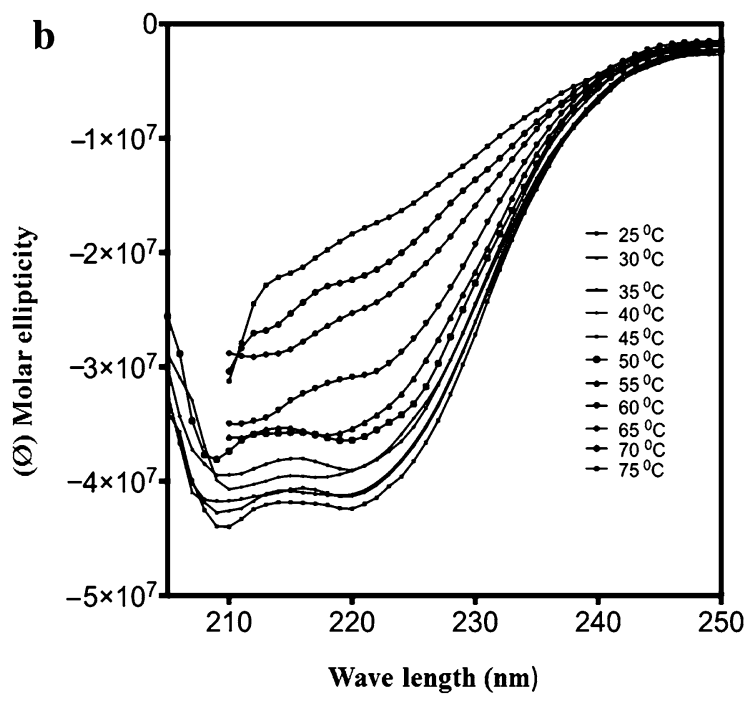

as function of secondary structure. Mung bean LOX was preincubated at given temperature for $10 \mathrm{~min}$ and measurements were made in $10 \mathrm{mM}$ phosphate buffer $(\mathrm{pH} 6.5)$

\section{References}

Axelrod B, Cheesbrough TM, Laakso S (1981) Lipoxygenase from soybeans. Methods Enzymol 71:441-451

Barone $\mathrm{R}$ et al (1999) Purification and characterization of a lipoxygenase enzyme from durum wheat semolina. J Agric Food Chem 47:1924-1931

Brash AR (1999) Lipoxygenases: occurrence, functions, catalysis, and acquisition of substrate. J Biol Chem 274:23679-23682

Chow Y et al (2007) Mung bean lipoxygenase in the production of a C6-aldehyde. Natural green-note flavor generation via biotransformation. Biotechnol J 2:1375-1380

Clemente A, Olías R, Olías JM (2000) Purification and characterization of broad bean lipoxygenase isoenzymes. J Agric Food Chem 48:1070-1075

Dainese E, Angelucci CB, Sabatucci A, De Filippis V, Mei G, Maccarrone M (2010) A novel role for iron in modulating the activity and membrane-binding ability of a trimmed soybean lipoxygenase-1. FASEB J 24:1725-1736

Devi P, Lakshmi KV, Reddy KJ, Reddanna P (2005) Differential expression of upoxygenase in green gram (Vigna radiata $\mathrm{L}$.). Legum Res Int J 28:87-93

Eriksson C, Svensson S (1970) Lipoxygenase from peas, purification and properties of the enzyme. Biochimica et Biophysica Acta (BBA) Enzymol 198:449-459

Feussner I, Wasternack C (2002) The lipoxygenase pathway. Ann Rev Plant Biol 53:275-297

Feussner I, Kuhn H, Wasternack C (2001) Lipoxygenase-dependent degradation of storage lipids. Trends Plant Sci 6(6):268-273

Gfeller A, Liechti R, Farmer EE (2010) Arabidopsis jasmonate signaling pathway. Sci Signal 3:109

Graff G, Anderson L, Jaques L (1990) Preparation and purification of soybean lipoxygenase-derived unsaturated hydroperoxy and hydroxy fatty acids and determination of molar absorptivities of hydroxy fatty acids. Anal Biochem 188:38-47

Haydar M, Hadziyev D (1973) A study of lipoxidase in pea seeds and seedlings. J Sci Food Agric 24:1039-1053

Heydeck D, Schewe T (1984) Improved procedure for the detection of activity of lipoxygenases on electropherograms. Biomed Biochim Acta 44:1261-1263

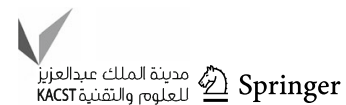


Joo YC, Oh DK (2012) Lipoxygenases: potential starting biocatalysts for the synthesis of signaling compounds. Biotechnol Adv 30:1524-1532

Kohyama N, Nagata T, SI Fujimoto, Sekiya K (1997) Inhibition of arachidonate lipoxygenase activities by 2-(3, 4-dihydroxyphenyl) ethanol, a phenolic compound from olives. Biosci Biotechnol Biochem 61:347-350

Kolomiets MV, Hannapel DJ, Chen H, Tymeson M, Gladon RJ (2001) Lipoxygenase is involved in the control of potato tuber development. Plant Cell 13:613-626

Kong D, Ju C, Parihar A, Kim S, Cho D, Kwak JM (2015) Arabidopsis glutamate receptor homolog AtGLR3.5 modulates cytosolic $\mathrm{Ca}^{2+}$ level to counteract effect of abscisic acid in seed germination. Plant Physiol 167:1630-1642

Kotapati KV, Bhagath Kumar P, Raveendra A, Thyagarju K, Dinakara rao A (2015) Cloning and characterization of lipoxygenase gene from germinating seedlings of green gram (Vigna radiata L.). Indian J Plant Physiol 20:345-352

Kuhn H, Thiele BJ (1999) The diversity of the lipoxygenase family. FEBS Lett 449:7-11

Kuo JM, Hwang A, Yeh DB, Pan MH, Tsai ML, Pan BS (2006) Lipoxygenase from banana leaf: purification and characterization of an enzyme that catalyzes linoleic acid oxygenation at the 9-position. J Agric Food Chem 54:3151-3156

Laemmli UK (1970) Cleavage of structural proteins during the assembly of the head of bacteriophage T4. Nature 227:680-685

Nagabhushana KS, Umamaheshwari S, Tocoli FE, Prabhu SK, Green IR, Ramadoss CS (2002) Inhibition of soybean and potato
Lipoxygenases by Bhilawanols from Bhilawan (Semecarpus anacardium) nut shell liquid and some synthetic Salicylic acid analogues. J Enzyme Inhib Med Chem 17:255-259

Rao A, Devi K, Thyagaraju K (1998) Isolation of antioxidant principle from azadzrachta seed kernels: determination of its role on plant lipoxygenases. J Enzym Inhib 14:85-96

Reddanna P, Whelan J, Maddipati K, Reddy CC (1990) Purification of arachidonate 5-lipoxygenase from potato tubers. Methods Enzymol 187:268-277

Rehbock B, Ganßer D, Berger R (1998) Efficient generation of 2Ehexenal by a hydroperoxide lyase from mung bean seedlings. Food Chem 63:161-165

Roopashree S, Singh S, Gowda L, Rao A (2006) Dual-function protein in plant defence: seed lectin from Dolichos biflorus (horse gram) exhibits lipoxygenase activity. Biochem J 395:629-639

Siedow JN (1991) Plant lipoxygenase: structure and function. Ann Rev Plant Biol 42:145-188

Suzuki T et al (2010) Effects of lipase, lipoxygenase, peroxidase and free fatty acids on volatile compound found in boiled buckwheat noodles. J Sci Food Agric 90:1232-1237

van Aarle PG, de Barse MM, Veldink GA, Vliegenthart JF (1991) Purification of a lipoxygenase from ungerminated barley Characterization and product formation. FEBS Lett 280:159-162

Weitbrecht K, Muller K, Leubner-Metzger G (2011) First off the mark: early seed germination. J Exp Bot 62(10):3289-3309 